See discussions, stats, and author profiles for this publication at: https://www.researchgate.net/publication/327261461

Ketimpangan Mutu dan Akses Pendidikan di Indonesia: Potret Berdasarkan Survei PISA 2015

Article · August 2018

CITATIONS

0

2 authors, including:

A Anindito Aditomo

Universitas Surabaya

30 PUBLICATIONS 138 CITATIONS

SEE PROFILE

Some of the authors of this publication are also working on these related projects:

Project Personal Epistemology and Learning View project
READS

259 


\title{
Ketimpangan Mutu dan Akses Pendidikan di Indonesia: Potret Berdasarkan Survei PISA 2015
}

\author{
Anindito Aditomo, Ph. D. (Fakultas Psikologi Universitas Surabaya) \\ Nisa Felicia, Ph. D. (Fakultas Pendidikan Universitas Sampoerna)
}

Terhitung sejak tahun 2017, Kementerian Pendidikan dan Kebudayaan (Kemendikbud) RI mengeluarkan kebijakan sistem zonasi dalam sistem penerimaan peserta didik baru (PPDB) dan disempurnakan di tahun 2018 melalui Permendikbud Nomor 14 Tahun 2018 yang menggantikan Permendikbud Nomor 17 Tahun 2017 tentang PPDB. Mengapa zonasi? Alasan utama yang dikemukakan adalah pemerintah ingin melakukan reformasi sekolah secara menyeluruh untuk melakukan pemerataan akses dan kualitas layanan pendidikan?

Tulisan ini menyajikan hasil kajian empiris yang dapat memperkaya diskusi mengenai urgensi kebijakan zonasi dan juga kebijakan lain yang berorientasi pada kesetaraan kesempatan pendidikan. Kajian ini mengacu pada dua pertanyaan besar. Pertama, terkait mutu pendidikan, yakni:
Siapa - atau siswa dengan latar belakang sosial ekonomi seperti apa - yang berada di sekolahsekolah yang mutunya lebih baik?

Berdasarkan penelitian terdahulu melalui berbagai konteks, hipotesis yang dapat dibangun adalah siswa dengan latar belakang sosial ekonomi yang lebih sejahtera berada di sekolah-sekolah yang lebih baik mutunya dibandingkan siswasiswa dengan latar belakang sosial ekonomi yang lebih rendah². Bila kajian ini mengkonfirmasi hipotesis di atas, maka dapat dikatakan bahwa ada masalah keadilan akses pendidikan. Untuk menjawab kedua pertanyaan tersebut, kami memanfaatkan data survei PISA (Programme for International Student Assessment) yang terakhir diselenggarakan pada tahun 2015. Kami memulai dengan memberi uraian singkat mengenai apa itu PISA, serta metode yang kami gunakan dalam menganalisis data PISA.

Seberapa besarkah kesenjangan mutu antar sekolah di Indonesia?

Di luar persepsi publik tentang keberadaan sekolah favorit dan bukan favorit, bukti ilmiah mengenai kesenjangan mutu pendidikan di Indonesia masih sulit ditemui. Kajian ini menyumbangkan estimasi kuantitatif mengenai kesenjangan mutu sekolah jenjang SMP dan SMA pada skala nasional di Indonesia. Apabila bukti menunjukkan adanya ketimpangan mutu, maka persoalan akses menjadi penting. Karena itu pertanyaan kedua yang kami kaji adalah:

PISA adalah sebuah survei internasional yang digagas oleh OECD (Organisation for Economic Co-operation and Development) untuk mengukur keterampilan kognitif siswa di berbagai negara. Dalam PISA, keterampilan kognitif yang diukur ditujukan pada aspek literasi, untuk memetakan kemampuan mengolah informasi dan menerapkan pengetahuan pada konteks baru. PISA mengukur tiga area literasi, yaitu literasi bahasa (membaca), literasi matematika, dan literasi sains ${ }^{3}$. 
Pertama, literasi membaca ditujukan untuk mengetahui kemampuan siswa dalam memahami, menggunakan, merefleksikan, dan menanggapi teks berdasarkan kontek. Kedua, literasi matematika ditujukan untuk mengetahui kemampuan bernalar siswa secara matematis dalam menggunakan konsep, prosedur, fakta, dan perangkat matematis ketika mendeskripsikan, menjelaskan, serta memprediksi fenomena. Ketiga, literasi sains ditujukan untuk mengetahui kemampuan siswa dalam menanggapi isu-isu sains dengan menggunakan gagasan-gagasan ilmiah.

Selain mengukur kemampuan literasi, survei PISA juga menggali data demografi terkait karakteristik psikologis serta latarbelakang siswa. Dalam tulisan ini, indikator mengenai latar belakang sosialekonomi siswa, yang selanjutnya disebut sebagai SES menjadi fokus analisis dalam penelitian. Indikator yang menjadi proksi SES pada laporan
PISA ditunjukkan melalui pendidikan orangtua, jumlah buku yang dimiliki di rumah, estimasi harta kekayaan keluarga (rumah, kendaraan, dll.), dan pekerjaan orangtua. Dalam PISA, indikatorindikator tersebut digabung menjadi satu indeks yang mewakili kondisi status sosial, ekonomi, dan budaya ${ }^{4}$.

Survei PISA dilaksanakan setiap tiga tahun sejak tahun 1997, dengan data terbaru yang tersedia berasal dari PISA 2015. PISA menerapkan sampling acak bertingkat. Artinya, di tiap negara, sejumlah sekolah dipilih secara acak dari daftar semua sekolah yang ada. Sejumlah siswa kemudian dipilih secara acak dari daftar siswa berusia 15 tahun di masing-masing sekolah. Prosedur sampling ini menghasilkan sampel yang mewakili populasi siswa berusia 15 tahun di tiap negara yang berpartisipasi. Di Indonesia, sampel PISA 2015 terdiri atas 6513 siswa dari 236 sekolah, sebagaimana ditunjukkan Tabel 1 berikut ini.

Tabel 1. Sampel PISA 2015 di Indonesia

\begin{tabular}{|c|c|c|c|}
\hline Jenjang & Jumlah sekolah & Jumlah siswa & Komposisi gender \\
\hline SMP (Kelas 9) & 118 & 3403 & $46.5 \%$ perempuan \\
\hline SMA (Kelas 10) & 118 & 3110 & $53.6 \%$ perempuan \\
\hline
\end{tabular}

\section{Metode Analisis}

Sebagaimana pemaparan sebelumnya, PISA menggunakan prosedur sampling bertingkat di mana sekolah dipilih secara acak terlebih dahulu, sebelum siswa di tiap sekolah dipilih secara acak. Prosedur ini menghasilkan sampel yang berkelompok dalam beberapa klaster. Maksudnya, kelompok siswa di sekolah yang sama memiliki kesamaan kondisi dalam hal proses belajar, fasilitas sekolah, dan lingkungan akademik.

Kajian ini menggunakan metode analisis yang disebut pemodelan multijenjang (multilevel modeling) atau hierarchical regression 5 . Pemodelan multijenjang adalah metode analisis yang dapat memisahkan varians skor pada level individu (variasi antar siswa) dari varians skor pada level kolektif, dalam hal ini variasi antar sekolah. Metode ini mengkuantifikasi kesenjangan mutu dengan menghitung apa yang disebut sebagai intra-class correlation (ICC). ICC merupakan proporsi varians skor literasi yang terjadi pada level sekolah, dibanding total varians skor literasi. Karena merupakan proporsi, ICC bergerak antara 0 sampai 100 persen. Semakin tinggi angka ICC, semakin besar pula kesenjangan mutu literasi antar sekolah.

Selain mengestimasi kesenjangan mutu, kajian ini juga hendak menggambarkan kesetaraan akses. Kesetaraan akses ini, dilihat dari kaitan 
antara latar belakang keluarga siswa dengan kemampuan literasinya. Latar belakang keluarga diukur menggunakan indeks SES PISA. Adanya kaitan positif antara SES dan tingkat literasi menunjukkan bahwa siswa yang berasal dari golongan sosial ekonomi tinggi memiliki peluang menunjukkan capaian yang lebih besar dibanding rekannya dari keluarga dengan golongan sosial ekonomi lebih rendah. Kaitan yang kuat antara SES dan tingkat literasi menandakan adanya ketidakadilan dalam akses pendidikan. Dengan menggunakan regresi multi-jenjang, tulisan ini memisahkan antara SES pada level siswa dan pada level kolektif (tingkat SES rata-rata sebuah sekolah). Keduanya penting dibedakan karena siswa dari keluarga dengan tingkat SES rendah mungkin saja bersekolah di sekolah yang sebagian besar siswanya memiliki tingkat SES menengah atau tinggi.

\section{Kesenjangan Mutu Sekolah}

\section{Seberapa besar kesenjangan antar sekolah di Indonesia dalam hal tingkat literasi siswanya?}

Tabel 2. Rerata dan variasi skor literasi dan tingkat sosial-ekonomi

\begin{tabular}{|c|c|c|}
\hline $\begin{array}{c}\text { Sekolah dan area } \\
\text { literasi }\end{array}$ & $\begin{array}{c}\text { Skor literasi } \\
\text { (rata-rata seluruh sampel) }\end{array}$ & $\begin{array}{c}\text { Variasi skor literasi antar } \\
\text { sekolah }\end{array}$ \\
\hline \multicolumn{3}{|c|}{ SMP (Kelas 9) } \\
\hline Matematika & 364 & $34.5 \%$ \\
\hline Bahasa & 378 & $29.7 \%$ \\
\hline Sains & 388 & $34.8 \%$ \\
\hline \multicolumn{3}{|c|}{ SMA (Kelas 10) } \\
\hline Matematika & 413 & $46.5 \%$ \\
\hline Bahasa & 422 & $35.5 \%$ \\
\hline Sains & 423 & $41.7 \%$ \\
\hline
\end{tabular}

Hasil analisis pada Tabel 2 menunjukkan bahwa variasi skor literasi antar sekolah berkisar antara 29.7\% (literasi bahasa siswa SMP) sampai 46.5\% (literasi matematika siswa SMA). Ini bermakna bahwa dari keseluruhan faktor yang mempengaruhi perbedaan capaian literasi adalah faktor sekolah.

Hasil analisis juga menunjukkan bahwa variasi skor antar sekolah meningkat dari tingkat SMP ke SMA. Dengan kata lain, kesenjangan mutu sekolah tampaknya menjadi semakin tajam di level SMA. Selain itu, hasil analisis data juga menunjukkan kesenjangan antar sekolah lebih tajam pada literasi matematika, dan paling kecil pada literasi bahasa.
Seberapa besarkah ketimpangan antar sekolah ini? Sebagai perbandingan, data PISA 2009 menghasilkan estimasi angka ICC berkisar 11\% di Finlandia, 27\% di Australia, 39\% di Singapura, dan 49\% di Indonesia ${ }^{6}$. Dengan demikian, ketimpangan antar sekolah di Indonesia dapat dikatakan relatif tinggi. Untuk memberi gambaran yang lebih jelas, kami membagi sekolah dalam sampel PISA menjadi tiga kategori berdasarkan skor literasi rata-rata tiap sekolah. Kategori pertama adalah 10\% sekolah dengan skor rata-rata paling rendah. Kategori kedua adalah sebagian besar sekolah (80\%) dengan skor rata-rata menengah. Kategori ketiga adalah 10\% sekolah dengan skor rata-rata paling tinggi. 


\section{SKOR RATA-RATA LITERASI (PISA) BERDASARKAN KATEGORI SEKOLAH}

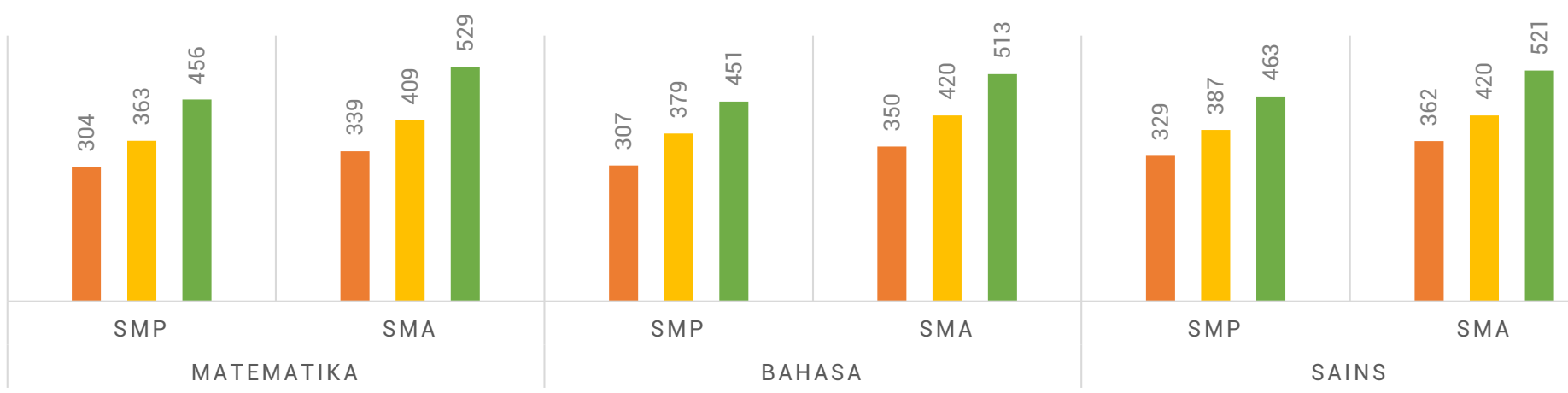

\footnotetext{
घ Sekolah dengan rerata SES siswa rendah (10\%)

- Sekolah dengan rerata SES setara/SES menengah (80\%)

• Sekolah dengan rerata SES siswa tinggi (10\%)
}

Grafik di atas memperlihatkan perbedaan sekolah (10\%) dengan capaian rendah dibandingkan dengan sebagian besar sekolah-dengan rerata skor- berkisar 60 poin untuk matematika. Ini hampir setara dengan lamanya 2 tahun pelajaran. Dengan kata lain, rata-rata siswa yang sekolahnya masuk dalam kategori bawah pelajaran matematikanya tertinggal 2 tahun dari siswa yang bersekolah di kategori yang lebih tinggi. Perbedaan antara sekolah (10\%) dengan kategori tinggi dibandingkan sebagian besar sekolah lain berkisar 70 sampai 120 poin. Iniartinya, setara dengan 2,5 sampai 4 tahun pelajaran. Dengan kata lain, siswa di sebagian besar sekolah di Indonesia tertinggal antara 2,5 sampai 4 tahun dibanding siswa di sekolah kategori tinggi. Hal ini mengindikasikan adanya ketimpangan mutu yang cukup besar antar sekolah menengah di Indonesia.

\section{Latar Belakang Sosial-Ekonomi dan Literasi}

Untuk melihat apakah latar belakang keluarga berkontribusi pada capaian literasi siswa, kajian ini menerapkan regresi multi-jenjang pada masing-masing area literasi (matematika, bahasa, dan sains). Analisis ini dilakukan guna melihat pengaruh SES keluarga pada level individu siswa dan pada level kolektif (SES rata-rata tiap sekolah) secara terpisah.

Hasil analisis menunjukkan bahwa SES individu secara signifikan berkontribusi terhadap peningkatan capaian literasi siswa. Dengan kata lain, semakin tinggi status sosial-ekonomi keluarga, semakin baik juga skor literasi seorang siswa, dan pola ini berlaku untuk siswa di semua sekolah partisipan PISA. Koefisien regresi SES individu dan skor literasi berkisar antara 4 sampai 6 poin. Artinya, dua siswa yang di sekolah yang sama namun berbeda 1 jenjang SES akan memiliki perbedaan skor literasi antara 4 sampai 6 poin. Sebagai ilustrasi, misalkan keluarga Ani memiliki status sosial-ekonomi satu tingkat lebih tinggi dibanding keluarga Dina. Meski keduanya berada di sekolah yang sama, kemungkinan besar Ani akan memiliki skor literasi sekitar 4-6 poin lebih tinggi dibanding Dina. Dengan demikian hasil analisis ini menunjukkan bahwa faktor sekolah saja tidak cukup menjelaskan kesenjangan hasil belajar antar siswa. 
Tabel 3. Keterkaitan antara SES dan Literasi

\begin{tabular}{|c|c|c|c|c|}
\hline \multirow{2}{*}{$\begin{array}{c}\text { Area literasi yang } \\
\text { diprediksi }\end{array}$} & \multicolumn{2}{|c|}{ Prediktor: SES siswa/individu } & \multicolumn{2}{c|}{ Prediktor: SES sekolah/kolektif } \\
\cline { 2 - 5 } & Koefisien regresi & Standard eror & Koefisien regresi & Standard eror \\
\hline \multicolumn{5}{|c|}{ SMP (Kelas 9) } \\
\hline Matematika & 6.795 & 1.727 & 33.382 & 5.215 \\
\hline Bahasa & 4.150 & 1.703 & 35.443 & 4.716 \\
\hline Sains & 3.943 & 1.483 & 32.364 & 4.481 \\
\hline \multicolumn{5}{|c|}{ SMA (Kelas 10) } \\
\hline Matematika & 8.457 & 1.737 & 40.024 & 5.038 \\
\hline Bahasa & 6.535 & 1.497 & 33.214 & 4.487 \\
\hline Sains & 4.673 & 1.406 & 34.264 & 4.165 \\
\hline
\end{tabular}

Keterangan: semua koefisien signifikan dengan $p<0.001$.

Pada level kolektif (rata-rata tiap sekolah), status sosial-ekonomi keluarga juga memiliki asosiasi yang positif dan signifikan dengan skor siswa untuk semua area literasi. Sekolah yang rata-rata siswanya berasal dari keluarga dengan SES tinggi menunjukkan skor literasi matematika, bahasa, dan sains yang lebih tinggi dibanding sekolah yang rata-rata siswanya berasal dari keluarga dengan SES rendah.

Dibanding SES level individu, SES kolektif memiliki kaitan yang lebih kuat dengan skor literasi. Koefisien regresi SES kolektif dalam berkisar antara 33-40 poin. Sebagai ilustrasi, misalkan Doni dan Ahmad berasal dari keluarga yang status sosial-ekonominya setara namun berada di sekolah yang berbeda karakteristik SES-nya, di mana Doni bersekolah dengan karakteristik
SES tinggi sementara Ahmad berada di sekolah dengan rerata SES rendah. Dengan demikian, dapat diduga bahwa skor Doni berkisar 33 sampai 40 poin lebih tinggi dibanding Ahmad.

Seberapa besar atau seriuskah perbedaan 3340 poin ini? Untuk menjawabnya, perlu diingat bahwa satu tahun pelajaran, secara rata-rata, setara dengan perbedaan 33 poin pada skala literasi PISA. Dengan demikian, dua sekolah yang berbeda satu level SES dapat dikatakan terpaut 1 tahun pelajaran. Padahal, sekolah paling "miskin" dan paling "kaya" terpaut sekitar 3,6 poin SSE dalam indeks PISA. Dengan kata lain, sekolahsekolah yang melayani siswa dari keluarga paling bawah tingkat SES-nya secara rata-rata tertinggal 3 sampai 4 tahun pelajaran dibanding sekolahsekolah yang melayani siswa dari keluarga dengan SES paling tinggi. 


\section{Implikasi dan Rekomendasi Kebijakan}

Analisis data yang dipaparkan pada subbab sebelumnya menunjukkan tiga poin penting terkait isu kesenjangan mutu pendidikan, terutama dalam perspektif latar belakang sosial ekonomi siswa.

Pertama, adanya kesenjangan mutu antar siswa di sekolah yang sama (within-school inequality) namun berasal dari keluarga dengan status sosial-ekonomi yang berbeda. Siswa dari keluarga dengan SES tinggi cenderung memiliki skor literasi yang lebih tinggi daripada teman-temannya di sekolah yang sama.

Kedua, kesenjangan juga ditemui antar sekolah yang memiliki tingkat SES kolektif yang berbeda. Dengan kata lain, SES rata-rata atau kolektif menjadi salah satu faktor yang menentukan kesenjangan mutu pendidikan sekolah menengah di Indonesia (betweenschool inequality). Siswa yang belajar di sekolah yang rata-rata siswanya dari keluarga golongan ekonomi tinggi mendapatkan keuntungan lebih dalam hal mutu pendidikan, dibanding mereka yang belajar di sekolah yang rata-rata siswanya dari keluarga dengan golongan ekonomi rendah.

Ketiga, terkait dengan dua hasil analisis di atas, uji statistik menunjukkan bahwa dibandingkan SES antar individu siswa, SES kolektif (antar sekolah) memiliki dampak lebih besar pada tingkat literasi siswa. Dalam estimasi kajian ini, dua sekolah yang berbeda satu jenjang SES kolektif memiliki selisih prestasi kolektif setara dengan satu tahun pelajaran. Temuan ini mendukung pendapat bahwa di Indonesia,

kesenjangan antar sekolah itu nyata dan berdampak serius pada kualitas hasil belajar siswa.
Tiga kesimpulan yang didapat dari hasil analisis di atas sebenarnya bukanlah hal yang baru. Borman dan Dowling 7 (2010) juga menemukan bahwa dalam konteks Amerika Serikat komposisi SES siswa di sekolah berpengaruh pada hasil belajar mereka, dan efeknya lebih besar daripada kesenjangan antar individu siswa menurut SES di satu sekolah. Dengan kata lain, kesenjangan antarsekolah lebih berdampak daripada kesenjangan antarsiswa. Di tingkat internasional, Willms $^{8}$ (2010) mendapatkan hasil serupa setelah menganalisis data PISA 2006 dengan sampel 57 negara. Hal ini menunjukkan bahwa pemerataan kualitas pendidikan perlu menjadi agenda utama di banyak negara. Berikut kami uraikan beberapa implikasi praktis untuk kebijakan dari temuantemuan ini.

Apabila ternyata terdapat kesenjangan SES antar zona, maka zonasi saja menjadi kurang efektif

Sebagaimana disampaikan di awal artikel ini, pemerataan kualitas pendidikan adalah alasan utama Kementerian Pendidikan dan Kebudayaan $\mathrm{RI}$ dalam menerapkan sistem penerimaan peserta didik baru (PPDB) menggunakan sistem zonasi. Melalui data empiris, penelitian ini menemukan bahwa kebijakan pemerataan pendidikan sudah mendesak diperlukan karena tingginya kesenjangan mutu pendidikan antar sekolah. 
Namun apakah zonasi merupakan jawaban untuk masalah kesenjangan yang secara nyata memang terjadi ini?

Analisis di atas menunjukkan bahwa karakteristik sekolah dengan rerata SES siswa tertentu memiliki kaitan erat dengan mutu sebuah sekolah. Dengan demikian, apabila zonasi dapat mengurangi kesenjangan SES antar sekolah, kebijakan tersebut berpotensi mengurangi kesenjangan mutu pendidikan. Dengan kata lain, zonasi akan efektif apabila kebijakan tersebut secara bertahap mampu mencegah pengelompokan siswa berdasarkan tingkat SES.

Perlu dicermati bahwa kajian ini tidak menjawab pertanyaan seperti "Di sekolah seperti apa pada umumnya siswa dengan SES tinggi belajar?", "Apakah mereka diajar guru yang lebih kompeten dan fasilitas yang lebih bagus?", "Apakah siswa miskin pada umumnya belajar di sekolah-sekolah dengan fasilitas yang minim?" atau variasi lain dari pertanyaan tentang dampak dari faktor-faktor sekolah dibanding faktor latar belakang keluarga siswa. Dengan kata lain, perlu penelitian lanjutan untuk mengetahui apakah ada kesenjangan fasilitas belajar, kualitas guru, dan lain-lain antara sekolah-sekolah yang rata-rata siswanya dari SES yang tinggi dibandingkan dengan yang rendah.

Apabila ternyata faktor-faktor sekolah tersebut juga terkait dengan kesenjangan mutu, maka zonasi perlu dipadu dengan kebijakan lain terkait distribusi guru dan sarana-prasarana sekolah. Namun, jika dampak SES menjadi tidak signifikan setelah memperhitungkan faktor-faktor sekolah, maka zonasi akan menjadi kurang efektif dalam mendistribusikan input siswa yang lebih merata karena faktor sekolah memainkan peran lebih penting dalam keberhasilan pendidikan siswa, terlepas dari keberagaman latar belakang SES mereka. Jika memang demikian yang terjadi, pemerintah perlu fokus pada pemerataan kualitas layanan pendidikan. Selain itu, apabila penelitian lain dapat menunjukkan bahwa sekolah-sekolah dalam satu zona dengan kualitas sumber daya rendah sementara di zona yang lain sekolah "favorit" berkumpul, maka zonasi justru dapat memindahkan kesenjangan dari level sekolah ke level zona. Namun sekali lagi, diperlukan kajian lanjutan untuk menelaah hal ini.

\section{Kuota Siswa Miskin}

Kajian ini menunjukkan bahwa zonasi bisa efektif sejauh kebijakan tersebut mampu mengurangi kesenjangan SES antar sekolah. Hal ini mengasumsikan bahwa terdapat keragaman SES dalam tiap zona sekolah. Apabila ternyata terdapat kesenjangan SES antar zona, maka zonasi saja menjadi kurang efektif. Dalam konteks inilah kebijakan kuota untuk siswa miskin (yang diatur dalam Peraturan Menteri Pendidikan dan Kebudayaan Republik Indonesia Nomor 14 Tahun 2019 Pasal 19) menjadi penting. Peraturan tersebut menyebutkan bahwa SMA/SMK Negeri wajib menerima siswa miskin sekurang-kurangnya $20 \%$ dari jumlah keseluruhan siswa yang diterima. Kebijakan tersebut dapatmendorong percampuran siswa dengan latar belakang SES yang berbeda, dengan harapan siswa dari keluarga miskin dapat meningkatkan kualitas hasil belajarnya ketika mereka berada di sekolah yang sama dengan mereka yang datang dari keluarga dengan SES yang lebih tinggi.

Namun demikian, pertanyaan yang sering muncul di publik adalah tidakkah kebijakan kuota ini akan merugikan siswa dengan SES tinggi karena dapat menyebabkan hasil belajar mereka menurun? Sebagaimana interpretasi hasil penelitian ini, di sekolah-sekolah dengan proporsi siswa miskin terlalu banyak, kualitas hasil belajar setiap individu cenderung lebih rendah. Oleh karena itu, asumsi kajian ini kuota $20 \%$ adalah hal yang layak dipenuhi agar siswa miskin tidak terkonsentrasi pada satu sekolah saja. Selain itu, siswa dari keluarga kelas atas memiliki sumberdaya untuk mendapatkan pembelajaran yang bermutu dari luar sekolah. 
Dengan demikian, dapat diduga bahwa keuntungan yang diperoleh siswa SES rendah akan lebih besar dibandingkan kerugian yang berpotensi dialami siswa dari SES tinggi.

Hal yang tak kalah penting dalam penerapan sistem zonasi adalah pemerintah perlu serius melakukan distribusi pemerataan guru-guru agar tidak lagi terpusat mengajar di sekolah-sekolah yang dilabeli favorit dimana mayoritas siswa datang dari latar belakang SES tinggi dan relatif homogen. Di samping itu, perlunya mengembangkan soft skill guru-guru untuk lebih terampil mengajar siswa dari keluarga SES rendah yang akan menyebabkan kelas menjadi heterogen. Belfi ${ }^{9}$ dan rekan-rekan (2015) menjelaskan bahwa salah satu faktor yang dapat menjelaskan adanya kesenjangan hasil belajar antar individu siswa dengan latar belakang SES yang berbeda adalah ekspektasi guru yang berbeda ketika menghadapi siswa dengan latar belakang SES yang berbeda. Mereka cenderung lebih percaya bahwa siswa dengan SES tinggi ataupun menengah lebih berpotensi daripada siswa dengan SES rendah. Ini adalah salah satu isu yang harus diantisipasi ketika sekolah semakin heterogen.

Kesimpulan dari kajian ini menunjukkan bahwa terdapat perbedaan kualitas hasil belajar antar siswa dikaitkan dengan mutu antar sekolah yang disebabkan oleh perbedaan status sosial ekonomi siswa sebagai faktor yang dapat menjelaskan kesenjangan ini. Terlebih lagi, komposisi siswa berdasarkan perbedaan SES di setiap sekolah berkontribusi pada tingkat literasi mereka. Hasil kajian ini menunjukkan bahwa kebijakan dan inisiatif untuk memperkecil kesenjangan antar sekolah perlu menjadi prioritas pemerintah. Tim peneliti memberikan saran bahwa kebijakan zonasi yang sudah mulai diimplementasikan pemerintah perlu terus didukung kebijakan peningkatan mutu pendidikan lainnya sehingga negara dapat memberikan kesempatan pendidikan yang lebih adil untuk anak-anak Indonesia 